\title{
PERAN DAI DALAM PEMBERDAYAAN UMAT MELALUI GREEN DAKWAH (Studi Terhadap Komunitas Peduli Lingkungan Pucang Rahayu Pucanganom, Srumbung, Magelang dan Komunitas Joglo Jeep Gunungpring, Muntilan, Magelang)
}

\author{
Azizah Herawati \\ Program Pasca Sarjana Magister Studi Islam \\ Universitas Muhammadiyah Yogyakarta \\ E-mail: azizah_hera@yahoo.co.id
}

\begin{abstract}
Abstrak
Penelitian bertujuan: mendeskripsikan peran dai dalam Green Dakwah, menjelaskan faktor pendukung dan penghambat keberhasilan Green Dakwah dan membandingkan Green Dakwah di Pucang Rahayu dan Joglo Jeep Gunungpring. Jenis penelitiannya deskriptif kualitatif. Lokasi penelitian di Komunitas Pucang Rahayu dan Komunitas Joglo Jeep Gunungpring. Tekhnik pengumpulan data melalui observasi, wawancara, perbincangan dan dokumentasi. Hasil penelitian: peran dai sangat dominan dalam kepedulian lingkungan, pemberdayaan dan pembinaan spiritual. Faktor pendukung Pucang Rahayu: dai tidak hanya ceramah, jamaah termotivasi untuk peduli lingkungan, berdaya, ikut kajian agama dan dukungan pemdes. Faktor penghambatnya: kesibukan jamaah, miskomunikasi pimpinan dan anggota serta minimnya kreator sampah. Faktor pendukung Komunitas Joglo Jeep: tersedianya sarpras dan dana, banyaknya komunitas yang berkumpul serta materi variatif dari berbagai disiplin ilmu. Faktor penghambatnya: sulitnya mengukur keberhasilan program, jamaah berganti-ganti. Perbedaannya: klaster, kuantitas pertemuan, segmen keanggotaan, target dakwah, jaringan serta materi.
\end{abstract}

Kata kunci: dai, green dakwah, peduli lingkungan

\begin{abstract}
The research aims to describe the role of dai in Green Dakwah, explaining the supporting factors and inhibiting the success of Green Dakwah and comparing Green Dakwah in Pucang Rahayu and Joglo Jeep Gunungpring. The research type is descriptive qualitative. Research location in Pucang Rahayu Community and Joglo Community Jeep Gunungpring. Techniques of data collection through observation, interviews, talks and documentation. The research results: the role of dai is very dominant in environmental awareness, empowerment and spiritual coaching. Supporting factors Pucang Rahayu: not only lectures, pilgrims are motivated to care about the environment, empowered, participate in religious studies and support pemdes. Inhibiting factors: the congregation of pilgrims, miscommunication of leaders and members and the lack of waste creators. Supporting factors Joglo Jeep Community: the availability of sarpras and funds, the number of communities that gather and varied material from various disciplines. Inhibiting factors: the difficulty of measuring the success of the program, the congregation alternated. The difference: cluster, meeting quantity, segment membership, target da'wah, network and material.
\end{abstract}

Keywords: dai, green da'wah, care for the environment

Info Artikel

Diterima Maret 2018, disetujui April 2018, diterbitkan Juni 2018

Dipublikasikan Oleh: Program Studi Bimbingan dan Konseling Fakultas Keguruan dan Ilmu Pendidikan Universitas PGRI Yogyakarta 


\section{PENDAHULUAN}

Dakwah sering dipersepsikan sebagai seruan kepada pengamalan keagamaan yang bersifat formal, tidak menyentuh aspek yang bersifat umum. Salah satunya yang berkaitan dengan pelestarian lingkungan. Padahal banyak dalil-dalil, baik Al-Qur'an maupun hadis Nabi Muhammad SAW yang menjelaskan pentingnya menjaga alam. Sehingga dakwah dikatakan ideal apabila mampu menyentuh aspek-aspek non formal. Salah satunya kepedulian terhadap lingkungan.

Ali Yafie dalam Khazanah Republika menyatakan bahwa selama ini ada lima komponen hidup yang harus dipelihara yakni hifdzul nafs (menjaga jiwa), hifdzul aql (menjaga akal), hifdzul maal (menjaga harta), hifdzul nasl (menjaga keturunan) dan hifdzud diin (menjaga agama). Namun setelah digali, masalah kerusakan lingkungan hidup menjadi masalah yang harus dijaga. Jadi menurutnya, hifdzul bi-ah (memelihara lingkungan hidup) patut dimasukkan ke dasar agama".

Di sisi lain, masyarakat mempersepsi peran seorang dai sebagai pelaku dakwah yang hanya berceramah. Padahal dibutuhkan masyarakat saat ini adalah aspek pemenuhan kebutuhan materiil, sehingga mereka harus diberdayakan. Peran dai yang ideal adalah mampu memberikan motivasi, mencarikan alternatif solusi serta melakukan pendampingan. Jadi, dai berperan sebagai fasilitator dakwah dan jamaah berperan sebagai mitra dakwah yang berjalan beriringan.

Berbicara tentang kepedulian lingkungan, tidak bisa dilepaskan dari masalah sampah. Selama ini sampah masih dipersepsikan negatif oleh sebagian besar masyarakat sebagai sesuatu yang kotor, bau dan harus dimusnahkan. Padahal apabila sampah dikelola dengan baik akan bermanfaat dan bernilai ekonomis. Dengan demikian, dai selaku fasilitator dakwah seharusnya bisa mengubah persepsi negatif tentang sampah dengan memberikan motivasi untuk peduli lingkungan, salah satunya dengan mengelola sampah. Sebagai upaya mengikuti trend kepedulian lingkungan dengan menggunakan kata green (hijau), maka istilah Green Dakwah sangat tepat untuk menyebut dakwah berbasis peduli lingkungan.

Komunitas Peduli Lingkungan Pucang Rahayu Pucanganom, Srumbung, Magelang merupakan salah satu komunitas yang melaksanakan gerakan Green Dakwah. Komunitas di pedesaan ini mengajak masyarakat untuk mengelola sampah sebagai wujud penyadaran untuk peduli lingkungan. Komunitas ini juga mengadakan kajian agama secara rutin bagi anggotanya. Dai bertindak sebagai fasilitator tidak terbatas ceramah, tetapi juga memotivasi untuk peduli lingkungan dengan didasari dalil-dalil agama. Dai juga memberikan pendampingan melalui sinergi dengan 
pihak lain untuk mendukung pemberdayaan ekonomi jamaah.

Adapun komunitas di kawasan perkotaan yang melakukan gerakan senada adalah Komunitas Joglo Jeep Gunungpring Muntilan, Magelang. Gerakannya lebih variatif, seperti kajian agama, budaya, sains, seni dan tekhnologi, dengan fokus pada kajian persampahan, yakni tekhnologi sampah dan aplikasinya. Komunitas ini terbuka untuk siapa saja yang ingin belajar, terutama yang terkait dengan gerakan peduli lingkungan.

Hal inilah yang menggugah minat peneliti untuk mengadakan penelitian pada kedua komunitas. Tujuannya untuk mengetahui metode yang digunakan dalam menggugah masyarakat tertarik untuk peduli lingkungan dan berdaya.

\section{KERANGKA TEORI}

\section{Metode Dakwah}

Dakwah merupakan sebuah seruan atau ajakan agar berbuat kebaikan dan melarang berbuat kemungkaran. Dakwah ditujukan kepada masyarakat secara menyeluruh untuk mewujudkan kesejahteraan masyarakat, baik di dunia maupun di akherat, sebagai cerminan dari Islam yang rahmatan lil-alamin.

\section{Macam-Macam Metode Dakwah}

Dalam rangka melaksanakan dakwah dibutuhkan metode yang disesuaikan dengan kondisi obyek dakwah, antara lain Dakwah Fardiyah yaitu dakwah yang dilakukan secara mandiri, Dakwah bi Al-lisan yaitu dakwah yang dilakukan secara lisan melalui ceramah di majlis-majlis, Dakwah bi Ar-Risalah yaitu dakwah dengan tulisan seperti membuat buku, menulis di surat kabar, majalah, buletin, booklet, leaflet dan lain-lain, Dakwah bi Al-Hal yaitu dakwah yang dilakukan dengan tindakan dan aksi nyata yang didasarkan pada kematangan seseorang dalam beragama sehingga bisa dijadikan inspirasi bagi orang lain untuk melakukan hal yang sama dan Dakwah Jamaah yaitu dakwah dengan melibatkan orang lain dalam jumlah tertentu sebagai sebuah sarana dakwah. Tujuannya memaksimalkan dan mengefektifkan pelaksanaan dakwah.

\section{Kompetensi Dai}

Dakwah tidak akan terwujud tanpa peran seorang dai. Masyarakat sering menyebut dai dengan istilah kiai. Kiai bagi sebagian masyarakat merupakan sumber pengetahuan, menjadi sumber referensi, fatwanya kuat, nasehatnya diikuti. Sebagaimana kiai, dai adalah orang yang melaksanakan dakwah Islam amar ma'ruf nahi mungkar secara tersistem, terencana dan berkesinambungan. Dia harus aktif dan memiliki kompetensi baik substantif (berhubungan dengan kepribadian dan pengetahuan dari dai itu sendiri) maupun metodologis (berhubungan dengan strategi dan 
metode dalam mengembangkan dakwah).

\section{Green Dakwah}

Green Dakwah merupakan istilah yang digunakan peneliti untuk menyebut gerakan dakwah berbasis peduli lingkungan. Hal ini diilhami seiring munculnya gerakan dengan branding pelestarian lingkungan menggunakan kata green yang berarti hijau.

Gerakan Green Dakwah menggunakan dakwah keagamaan sebagai salah satu metode dalam melakukan pendekatan kepada jamaah untuk peduli lingkungan. Karena secara eksplisit, Al-Qur'an menyatakan bahwa segala jenis kerusakan yang terjadi di permukaan bumi ini merupakan akibat dari ulah tangan manusia itu sendiri.

Ar-Rum [30]: 41)

Rasulullah Muhammad SAW juga menegaskan bahwa Allah SWT itu indah dan mencintai keindahan.(H.R. At

Tirmidzi).Dikuatkan juga oleh sabda Rasulullah SAW yang menegaskan bahwa kebersihan itu merupakan wujud dari keimanan.(HR Muslim)

Green Dakwah merupakan gerakan dakwah dengan metode dakwah bi al-hal, berupa tindakan dan aksi nyata, didasarkan pada kematangan dai sebagai fasilitator dakwah dalam beragama sehingga bisa dijadikan inspirasi bagi jamaah selaku mitra dakwah untuk melakukan hal yang sama.
Ruang lingkup dari Green Dakwah meliputi tiga aspek, yaitu: Pertama, Peduli Lingkungan, yaitu upaya menumbuhkan kesadaran peduli lingkungan sebagai usaha untuk mengubah persepsi negatif masyarakat tentang sampah yang dianggap kotor, bau, tidak bermanfaat dan harus dimusnahkan. Sampah adalah zat atau benda sisa kegiatan sehari-hari manusia yang sudah tidak terpakai lagi, apabila disikapi dengan tidak tepat akan menimbulkan dampak negatif. Dalam teori psikologi komunikasi, persepsi adalah pengalaman tentang objek, peristiwa atau hubungan-hubungan yang diperoleh seseorang dengan menyimpulkan informasi dan menafsirkan pesan. Persepsi negatif masyarakat tentang sampah harus diluruskan dengan menyatakan bahwa sampah jika diperlakukan dengan baik, bisa dimanfaatkan kembali, bernilai ekonomis dan terlihat indah saat dikreasikan.

Kedua, Pemberdayaan Umat. Upaya mengubah persepsi masyarakat tentang sampah akan memunculkan emosi positif. Suasana hati yang positif akan memperluas perhatian seseorang terhadap sesuatu, wawasan menjadi luas dan peluangpun terbuka. Dengan emosi positif, manusia bisa mengembangkan jaringan, mampu menghadapi kesulitan hidup dan berpikir lebih kreatif. Emosi positif juga berfungsi sebagai penanda kesejahteraan, sebuah upaya mengatasi stres sehingga mampu 
melihat sesuatu dengan lebih obyektif. Menghadapi fenomena sampah dengan emosi positif yang dikelola, maka sampah menadi aset yang mendatangkan income. Dalam teori motivasi, digunakan pendekatan insentif di mana sumber motivasinya berasal dari sebuah keinginan untuk memperoleh tujuan eksternal yang berharga. Nilai, uang, afeksi, makanan maupun seks merupakan hal yang diperhitungkan dari motivasi seseorang. Dalam hal ini para psikolog sepakat menggabungkan dengan teori drive-reduction, keduanya sama-sama menarik orang untuk berperilaku.

Ketiga, Pembinaan Spiritual, merupakan ciri khas dari Green Dakwah yang membedakan dengan komunitas lain dengan kajian agama. Dalam teori motivasi, digunakan pendekatan drive-reduction (pengurangan dorongan). Teori ini tidak membatasi kebutuhan itu berbentuk biologis, sosiologis maupun ketuhanan. Sebagai contoh kebutuhan minum didorong oleh rasa haus, kebutuhan akan ketenangan jiwa didorong oleh keinginan mendekatkan diri pada Tuhan.

Dalam Green Dakwah, pola komunikasi yang tepat sangat dibutuhkan, karena melibatkan beberapa personil dalam sebuah kelompok. Mereka saling berhubungan dan tidak bisa menghindari proses komunikasi. Teori komunikasi yang diterapkan dalam Green Dakwah yaitu Komunikasi Interpersonal yakni proses pemindahan informasi antara dua orang atau lebih, masing-masing berusaha memberikan arti pada pesan simbolik yang dikirim melalui media dan menimbulkan umpan balik.

Selain itu juga digunakan Komunikasi Kelompok yang memerlukan adanya tujuan dan organisasi meski tidak formal, melibatkan interaksi sesama anggota, ada sense of belonging yang tidak dimiliki orang di luar kelompoknya dan saling bergantung untuk mendapatkan hasil yang diinginkan.

Peran dai selaku fasilitator dakwah merupakan salah satu kunci keberhasilan Green Dakwah. Kemampuan dai tidak hanya bersifat fardiyah atau mandiri saja, tapi harus mampu bekerja dengan tim melalui dakwah jamaah. Dai dalam harus berwawasan luas, baik ilmu agama maupun ilmu-ilmu lain. Kemampuan membangun jaringan dan kerjasama merupakan sebuah keniscayaan bagi seorang dai.

\section{METODE PENELITIAN}

Penelitian ini merupakan penelitian lapangan ( field research) dengan pendekatan deskriptif kualitatif, yaitu penelitian yang menggunakan gambaran peristiwa atau fenomena yang ada dengan paparan berupa data-data berbentuk informasi dan kata-kata.

Penelitian ini berhubungan erat dengan antropologi dakwah, karena merupakan instrumen yang tepat untuk memahami fenomena sosial 
yang terjadi di masyarakat karena pengaruh globalisasi termasuk fenomena keagamaan masyarakat. Pendekatan antropologis diperlukan karena yang agama hanya bisa dibicarakan secara tuntas melalui pendekatan antropologis. Antropologi lebih mengedepankan pengamatan langsung dengan cara turun ke lapangan sebagai sebuah upaya membebaskan diri dari teori yang bersifat formal, sangat abstrak dan matematis.

\section{Lokasi dan Subyek Penelitian}

Lokasi penelitian ini adalah KPL Pucang Rahayu Pucanganom, Srumbung, Magelang dan Komunitas Joglo Jeep Gunungpring, Muntilan, Magelang. Penentuan Subyek penelitian dengan menggunakan criterian based terdiri dari pengurus kedua komunitas, fasilitator atau dai, anggota dan pihak-pihak dari lembaga mitra. Adapun tekhnik pengumpulan data yang digunakan adalah Obsevasi Berperan Serta , Wawancara Mendalam, Perbincangan dan Dokumentasi.

\section{HASIL DAN PEMBAHASAN \\ Peran Dai dalam Pelaksanaan Green Dakwah}

Analisis peran dai dalam
pelaksanaan Green Dakwah
dihubungkan dengan ruang lingkup
Green Dakwah dideskripsikan sebagai
berikut:

\section{Peduli Lingkungan}

Peran dai di dua komunitas sangat dominan. Dai mengajak jamaah untuk peduli lingkungan dengan mengungkapkan dalil-dalil Al-Qur'an, sehingga jamaah termotivasi untuk mengamalkannya. Inti dari gerakan ini adalah bagaimana masyarakat memandang bahwa dai itu tidak sekedar ceramah tapi mampu memotivasi jamaah untuk melakukan sesuatu yang bermanfaat bagi diri dan orang lain, salah satunya dengan mengelola sampah.

Dai memotivasi jamaah dengan mengajak sambil memberi contoh, seperti membuang sampah pada tempatnya, menyapu halaman dan lain-lain, dakwah bi a-hal. Membangkitkan peduli lingkungan dari rumah, sampah dibersihkan dan dimanfaatkan.

\section{Pemberdayaan Umat}

Peran dai dalam memberdayakan umat pada dua komunitas ini sangat dominan, meskipun tidak berperan secara mandiri namun ada dukungan pihakpihak lain sesuai bidangnya.

Dai mengajak jamaah untuk memanfaatkan sampah untuk dijual dan dikreasi menjadi kerajinan,sehingga menambah masukan uang". Motivasi dai dalam memberdayakan jamaah menurut dai fasilitator adalah karena jamaah berhak mendapatkan sesuatu yang bersifat materi dari gerakan ini. Harapannya dengan mengelola 
sampah dan mengaji, akan tercipta lingkungan bersih, spiritual dan ekonomi juga terpenuhi".

Dai juga memberdayakan jamaah dengan mengajak untuk bersungguh-sungguh dalam menekuni apa yang sudah menjadi pekerjaannya. Prinsipnya kemandirian dan mau berbagi.

\section{Pembinaan Spiritual}

Dakwah dengan kajian agama merupakan branding yang membedakan dengan komunitas sampah pada umumnya. Fasilitator di KPL Pucang Rahayu merasa sangat senang dan mengapresiasi positif adanya muatan kajian agama pada komunitas ini, karena sangat langka dan hampir tidak ada. Adanya taushiyah agama juga menenangkan hati.

Hasil penelitian tersebut menunjukkan adanya aspek-aspek yang merupakan teori-teori dalam antropologi dakwah dan psikologi komunikasi. Peran dai selaku fasilitator dakwah telah mampu:

1. Mengubah persepsi jamaah bahwa cakupan ajaran Al-Qur'an bersifat universal, rahmatan lil-alamin termasuk di dalamnya perintah untuk menjaga kelestarian lingkungan.

2. Mengubah persepsi masyarakat terhadap metode dakwah yang selama ini hanya ceramah dengan metode yang lain.

3. Mengubah emosi negatif jamaah terhadap sampah dengan menumbuhkan emosi positif untuk mengelola sampah menjadi sesuatu yang bermanfaat.

4. Membangkitkan motivasi jamaah untuk peduli terhadap lingkungan.

5. Membangkitkan motivasi insentif untuk mendapatkan keuntungan ekonomi dari kegiatannya.

6. Melakukan pendekatan drive reduction kepada jamaah untuk tidak hanya tercukupi materi, tetapi juga kebutuhan rohani.

7. Memotivasi jamaah mengaktualisasikan diri untuk rela melakukan sesuatu yang berbeda dengan gerakan peduli lingkungan sebagai penerapan dari teori kebutuhan Maslow saat seseorang berkesempatan mengembangkan potensinya.

8. Mengembangkan metode dakwah dari dakwah bi al-lisan menjadi dakwah bi al-hal, dari dakwah fardiyah menjadi dakwah jamaah sehingga hasil yang dicapai lebih maksimal.

9. Menggunakan pendekatan antropologi dalam berdakwah melalui pensinergian kajian agama dan pelestarian lingkungan hidup.

Faktor Pendukung dan Penghambat Keberhasilan Pelaksanaan Green Dakwah

\section{Faktor Pendukung Keberhasilan} KPL Pucang Rahayu

Apabila dihubungkan dengan ruang lingkup Green Dakwah dalam menganalisis faktor pendukung keberhasilan KPL Pucang Rahayu, 
maka dapat dipaparkan dalam tabel berikut ini:

Tabel 1

Faktor pendukung keberhasilan Green Dakwah KPL Pucang Rahayu

\begin{tabular}{|c|c|c|c|}
\hline NO. & UNSUR & KEBERHASILAN & FAKTOR PENDUKUNG \\
\hline 1. & $\begin{array}{c}\text { Peduli } \\
\text { Lingkungan }\end{array}$ & $\begin{array}{l}\text { Berubahnya persepsi } \\
\text { jamaah tentang sampah } \\
\text { Mewakili kecamatan } \\
\text { mengikuti lomba Bank } \\
\text { Sampah } \\
>\text { Menjadi tempat study } \\
\text { banding pengelolaan } \\
\text { sampah dari berbagai } \\
\text { komunitas dan daerah } \\
\text { Kegiatannya terpublikasi } \\
\text { secara luas melalui } \\
\text { media masa dan media } \\
\text { sosial }\end{array}$ & $\begin{array}{l}\text { Dai memotivasi dengan } \\
\text { dasar-dasar agama } \\
\text { Kesungguhan anggota } \\
\text { dalam mengelola Bank } \\
\text { Sampah } \\
\text { Solid kompaknya anggota } \\
\text { yang didukung penuh oleh } \\
\text { pemangku kebijakan } \\
\text { setempat } \\
\\
\text { Peran dai dan anggota } \\
\text { komunitas dalam publikasi } \\
\text { dan bekerjasama dengan } \\
\text { berbagai pihak }\end{array}$ \\
\hline 2 . & $\begin{array}{c}\text { Pemberdaya } \\
\text { an Umat }\end{array}$ & $\begin{array}{l}\text { Sampah yang sudah } \\
\text { dipilah menghasilkan } \\
\text { income } \\
\text { Jamaah mampu } \\
\text { menghasilkan kreasi } \\
\text { berbahan dasar sampah } \\
\text { baik untuk dipakai } \\
\text { sendiri maupun dijual } \\
\text { Komunitas mendapatkan } \\
\text { support dana dari } \\
\text { berbagai pihak untuk } \\
\text { mendukung kegiatan } \\
\end{array}$ & $\begin{array}{l}\text { Dai dan fasilitator mampu } \\
\text { mengubah persepsi jamaah } \\
\text { terhadap sampah } \\
\text { Adanya pelatihan } \\
\text { pembuatan kreasi berbahan } \\
\text { sampah dan direspon } \\
\text { positif oleh jamaah serta } \\
\text { membangun jaringan } \\
\text { pemasaran produk } \\
\text { Dai, fasilitator dan Pemdes } \\
\text { membangun jaringan untuk } \\
\text { pendanaan }\end{array}$ \\
\hline 3. & $\begin{array}{c}\text { Pembinaan } \\
\text { Spiritual }\end{array}$ & $\begin{array}{l}\text { Berubahnya persepsi } \\
\text { jamaaah tentang peran } \\
\text { dai yang selama ini } \\
\text { hanya ceramah } \\
>\text { Jamaah antusias } \\
\text { mengikuti kajian agama }\end{array}$ & $\begin{array}{l}\text { Dai mampu mengubah } \\
\text { persepsi jamaah tentang } \\
\text { peran dai yang tidak hanya } \\
\text { ceramah } \\
\text { Dai tidak hanya ceramah, } \\
\text { tapi juga memberikan } \\
\text { pendampingan, baik untuk } \\
\text { sharing permasalahan } \\
\text { maupun membangun } \\
\text { jaringan }\end{array}$ \\
\hline
\end{tabular}


Faktor Penghambat Keberhasilan

\section{KPL Pucang Rahayu}

Faktor penghambat keberhasilan pelaksanaan Green Dakwah di KPL Pucang Rahayu salah satunya dari unsur internal yaitu adanya miskomunikasi antara ketua dan anggota. Ketua kurang aktif karena suatu hal, tapi tidak komunikasi dengan anggota. Selain itu partisipasi jamaah tidak stabil dan cenderung menurun sehingga perlu dibangun soliditas jamaah. Ketua KPL Pucang Rahayu juga mengatakan bahwa kualitas dan kuantitas komunikasi antara dia selaku ketua dengan jamaah memang cenderung menurun, karena sibuk dengan urusan lain, sehingga memang perlu adanya penyadaran terhadap jamaah untuk rutin mengikuti kegiatan di komunitas.
Di sisi lain, ada yang mengatakan tidak ada kendala secara internal. Kendalanya justru dari luar terkait sulitnya menyadarkan masyarakat yang bukan anggota untuk mau mengelola sampah. Sebagian besar anggota KPL Pucang Rahayu adalah kader PKK Desa dengan kegiatan yang sangat padat. Sehingga tidak bisa maksimal mengikuti kegiatan di KPL Pucang Rahayu. Selain itu karena terbatasnya kader pembuat kreasi sampah yang mumpuni dan masih sulitnya memasarkan hasil kreasi".

Setelah dianalisis berdasarkan paparan hasil penelitian di atas maka penghambat keberhasilan KPL Pucang Rahayu dapat dideskripsikan dalam bentuk tabel berikut ini:

\section{Tabel 2}

Faktor penghambat keberhasilan Green Dakwah KPL Pucang Rahayu

\begin{tabular}{|l|l|}
\hline \multicolumn{2}{|c|}{ FAKTOR PENGHAMBAT KEBERHASILAN KPL PUCANG RAHAYU } \\
\hline \multicolumn{1}{|c|}{ Faktor Internal } & \multicolumn{1}{c|}{ Faktor Eksternal } \\
\hline $\begin{array}{l}\text { Masih belum stabilnya jamaah untuk } \\
\text { istiqomah menghadiri pertemuan }\end{array}$ & $\begin{array}{l}\text { Sulitnya menyadarkan } \\
\text { masyarakat tentang pengelolaan } \\
\text { sampah }\end{array}$ \\
\hline $\begin{array}{l}\text { Mulai melemahnya komunikasi antara ketua } \\
\text { dan anggota komunitas baik secara } \\
\text { interpersonal maupun organisasi }\end{array}$ & $\begin{array}{l}\text { Banyaknya kegiatan di luar } \\
\text { komunitas yang menyebabkan } \\
\text { intensitas pertemuan berkurang }\end{array}$ \\
\hline $\begin{array}{l}\text { Minimnya anggota yang mumpuni dalam } \\
\text { pembuatan kreasi berbahan dasar sampah }\end{array}$ & $\begin{array}{l}\text { Sulitnya mencari pasar untuk } \\
\text { penjualan hasil kreasi }\end{array}$ \\
\hline
\end{tabular}

Faktor Pendukung Keberhasilan Komunitas Joglo Jeep Gunungpring Apabila dihubungkan dengan ruang lingkup Green Dakwah dalam menganalisis faktor pendukung keberhasilan Komunitas Joglo Jeep
Gunungpring, maka dapat dipaparkan dalam tabel berikut ini: 
Tabel 3

Faktor pendukung keberhasilan Green Dakwah Komunitas Joglo Jeep Gunungpring

\begin{tabular}{|c|c|c|c|}
\hline NO. & UNSUR & KEBERHASILAN & FAKTOR PENDUKUNG \\
\hline 1. & $\begin{array}{c}\text { Peduli } \\
\text { Lingkungan }\end{array}$ & $\begin{array}{l}\text { Menjadi tempat } \\
\text { pembelajaran berbagai } \\
\text { disiplin ilmu terutama } \\
\text { terkait kepedulian } \\
\text { lingkungan } \\
>\text { Menjadi tempat } \\
\text { berkumpulnya berbagai } \\
\text { komunitas dengan misi } \\
\text { peduli lingkungan } \\
>\text { Jamaah termotivasi } \\
\text { untuk mengelola } \\
\text { sampah di komunitas } \\
\text { masing-masing }\end{array}$ & $\begin{array}{l}\text { Pemateri handal dari berbagai } \\
\text { daerah, akademisi, bahkan luar } \\
\text { negeri dari berbagai disiplin } \\
\text { ilmu } \\
>\text { Tersedianya sarana dan } \\
\text { prasarana serta pendanaan } \\
\text { yang memadai dari pengurus } \\
\text { komunitas } \\
>\text { Apapun acaranya selalu ada } \\
\text { motivasi untuk menjaga bumi } \\
\text { terutama ilmu persampahan }\end{array}$ \\
\hline 2. & $\begin{array}{c}\text { Pemberdaya } \\
\text { an Umat }\end{array}$ & $\begin{array}{l}\text { Jamaah termotivasi } \\
\text { untuk berdaya melalui } \\
\text { berbagai aspek sesuai } \\
\text { hobi dan bakat masing- } \\
\text { masing } \\
>\text { Jamaah termotivasi } \\
\text { mengelola dan } \\
\text { memanfaatkan sampah } \\
\text { menjadi sumber } \\
\text { ekonomi }\end{array}$ & $\begin{array}{l}\text { Adanya motivasi ekonomi dari } \\
\text { fasilitator dan narasumber } \\
\text { handal yang kompeten di } \\
\text { bidangnya } \\
\text { Adanya pelatihan inovatif } \\
\text { terkait pengelolaan dan } \\
\text { pemanfaatan sampah dari } \\
\text { tenaga ahli }\end{array}$ \\
\hline 3. & $\begin{array}{c}\text { Pembinaan } \\
\text { Spiritual }\end{array}$ & $\begin{array}{l}\text { Selalu ada materi } \\
\text { kerohanian sebagai } \\
\text { penyeimbang motivasi } \\
\text { lingkungan dan } \\
\text { ekonomi }\end{array}$ & $\begin{array}{l}\text { Adanya materi dari dai } \\
\text { variatif, tidak formal, dialogis, } \\
\text { siap menerima sharing dan } \\
\text { curhat }\end{array}$ \\
\hline
\end{tabular}

Faktor Penghambat Keberhasilan Komunitas Joglo Jeep Gunungpring Tabel 4

Faktor penghambat keberhasilan Green Dakwah Komunitas Joglo Jeep Gunungpring

\begin{tabular}{|l|l|}
\hline \multicolumn{2}{|c|}{ FAKTOR PENGHAMBAT KEBERHASILAN } \\
KOMUNITAS JOGLO JEEP GUNUNGPRING \\
\hline \multicolumn{1}{|c|}{ Faktor Internal } & \multicolumn{1}{c|}{ Faktor Eksternal } \\
\hline $\begin{array}{l}\text { Komunitas bersifat menfasilitasi kegiatan } \\
\text { berbagai macam komunitas }\end{array}$ & $\begin{array}{l}\text { Masih adanya persepsi masyarakat } \\
\text { yang menilai dakwah itu hanya } \\
\text { ceramah }\end{array}$ \\
\hline Keberhasilan sulit diukur karena jamaah & Ceramah agama tentang lingkungan \\
\hline
\end{tabular}




\begin{tabular}{l|l|}
\hline $\begin{array}{l}\text { sebagai mitra dakwah berganti-ganti, tidak } \\
\text { tetap }\end{array}$ & masih dianggap aneh \\
\hline $\begin{array}{l}\text { Dai selaku fasilitator dakwah berganti- } \\
\text { ganti, bersifat insidental sehingga kurang } \\
\text { ada kesinambungan }\end{array}$ & $\begin{array}{l}\text { Sulitnya menyatukan visi dan misi } \\
\text { dari berbagai komunitas yang } \\
\text { berbeda dan domisili yang berjauhan }\end{array}$ \\
\hline
\end{tabular}

Pada prinsipnya semua kegiatan di komunitas sangat variatif, inovatif dan layak jadi kiblat untuk trend baru di bidang kepedulian lingkungan. Beberapa hambatan tersebut bisa dijadikan bahan evaluasi, untuk ditata kembali tekhnis pelaksanaannya. Komunikasi yang baik dengan pemangku kebijakan setempat harus segera dibangun supaya bisa bersinergi. Dimulai dari komunikasi interpersonal antara fasilitator dengan pejabat setempat berlanjut ke komunikasi yang lebih luas.
Perbandingan Pelaksanaan Green

Dakwah pada KPL Pucang Rahayu

dan Komunitas Joglo Jeep

\section{Gunungpring}

Persamaan

Bedasarkan hasil penelitian yang dilakukan peneliti terhadap kedua komunitas, ditemukan beberapa persamaan, antara lain: keduanya bergerak di bidang kepedulian lingkungan, menggunakan kajian Islam sebagai sarana dakwah dan membangkitkan jamaah untuk berdaya melalui pengelolaan sampah.

\section{Perbedaan}

Selain adanya persamaan, antara kedua komunitas ini juga mempunyai perbedaan dalam melaksanakan Green Dakwah Perbedaan tersebut dapat dilihat bagan sebagai berikut:

Tabel 5

Perbedaan pelaksanaan Green Dakwah

\begin{tabular}{|c|c|c|c|}
\hline \multirow[b]{2}{*}{ NO. } & \multirow{2}{*}{$\begin{array}{c}\text { FAKTOR } \\
\text { PEMBEDA }\end{array}$} & \multicolumn{2}{|c|}{ KOMUNITAS } \\
\hline & & Pucang Rahayu & Joglo Jeep Gunungpring \\
\hline $\begin{array}{l}1 . \\
2 . \\
3 .\end{array}$ & $\begin{array}{l}\text { Lokasi/ Klaster } \\
\text { Volume } \\
\text { Kegiatan } \\
\text { Jenis Kegiatan }\end{array}$ & $\begin{array}{l}\text { Pedesaan } \\
\text { Rutin } \\
\text { Kajian Islam, } \\
\text { Lingkungan dan } \\
\text { Ketampilan }\end{array}$ & $\begin{array}{l}\text { Perkotaan } \\
\text { Insidental } \\
\text { Kajian Islam, Lingkungan } \\
\text { dan Kajian inovatif lainnya } \\
\text { Berganti-ganti } \\
\text { Semua kalangan dari }\end{array}$ \\
\hline
\end{tabular}




\begin{tabular}{|c|l|l|l|}
\hline 4. & $\begin{array}{l}\text { Dai Fasilitator } \\
\text { Segmen Jamaah }\end{array}$ & $\begin{array}{l}\text { Tetap } \\
\text { Ibu-ibu }\end{array}$ & $\begin{array}{l}\text { berbagai komunitas } \\
\text { Tidak Tetap/Berbagai } \\
\text { Komunitas } \\
\text { Ketua Komunitas } \\
\text { Tetap/ Khusus Anggota } \\
\text { Tidak Ada } \\
\text { Komunitas } \\
\text { Berbagai pihak }\end{array}$ \\
$\begin{array}{l}\text { Jamaah yang } \\
\text { hadir }\end{array}$ & $\begin{array}{l}\text { Sumber Dana } \\
\text { Hubungan } \\
\text { dengan Desa } \\
\text { setempat }\end{array}$ & $\begin{array}{l}\text { Ada } \\
\end{array}$ & \\
\hline
\end{tabular}

Meskipun kedua komunitas terkesan memiliki perbedaan yang signifikan, baik dari segi klaster, kuantitas dan kualitas, peran dai selaku fasilitator dakwah, materi yang disampaikan, namun keduanya bisa saling bersinergi dan berhubungan satu sama lain. Hal ini terbukti dari beberapa kesempatan KPL Pucang Rahayu juga sering mengikuti kegiatan-kegiatan yang diadakan oleh Joglo Jeep Gunungpring.

Green dakwah juga mendapatkan apresiasi positif dari berbagai pihak menyatakan bahwa Green Dakwah merupakan wadah bagi dai untuk mengembangkan kompetensinya untuk membangkitkan masyarakat berpikir luas termasuk masalah lingkungan. Green Dakwah juga dinilai sangat efektif dalam membangun kesadaran untuk peduli lingkungan dengan dalil-dalil agama sebagai dasarnya.

\section{KESIMPULAN}

Berdasarkan hasil penelitian dan pembahasan yang peneliti lakukan, maka dapat diperoleh kesimpulan sebagai berikut:
1. Peran dai selaku fasilitator dakwah sangat dominan dalam pelaksanaan Green Dakwah terkait kepedulian lingkungan, pemberdayaan umat dan pembinaan spiritual.

2. Keberhasilan KPL Pucang Rahayu didukung oleh berubahnya persepsi jamaah terhadap dakwah yang terkait metode dan materi dakwah, termotivasinya jamaah untuk peduli lingkungan dan ikut kajian agama serta adanya dukungan dari pemangku kebijakan setempat. Penghambatnya adalah menurunnya tingkat partisipasi jamaah karena kesibukan, menurunnya kualitas dan kuantitas komunikasi antara pimpinan dan anggota serta minimnya tenaga ahli kreasi sampah. Faktor pendukung keberhasilan Komunitas Joglo Jeep Gunungpring didukung oleh sarpras, dana yang memadai serta banyaknya komunitas yang berkumpul dan sharing dengan misi peduli lingkungan didukung fasilitator dan pemateri yang handal dari berbagai disiplin ilmu. 
Penghambatnya adalah sulitnya mengukur keberhasilan program karena jamaah berganti-ganti dengan berbagai macam latar belakang.

3. Perbedaan antara kedua komunitas sangat signifikan baik dari segi klaster, kuantitas dan kualitas pertemuan, peran dai selaku fasilitator dakwah serta materi yang disampaikan namun, keduanya dengan kelebihan dan kekurangan masing-masing saling bersinergi dan berhubungan satu sama lain.

\section{DAFTAR PUSTAKA}

Al-Firdaus, Laila Kholid, "Islam and Local Politics; In the Quest of Kiai, Politics and Development in Kebumen 2008-2010" dalam Jurnal of Islamic Studies AlJami'ah, Volume 51. No.2. Yogyakarta: UIN Sunan Kalijaga, 2013

Laksana, Muhibudin Wijaya, Psikologi Komunikasi Membangun Komunikasi yang Efektif dalam Interaksi Manusia, Bandung: Pustaka Setia, 2015

Lembaga Pengembangan Cabang dan Ranting Pimpinan Pusat Muhammadiyah, Pengelolaaan Korps Mubaligh Cabang Muhammadiyah, Yogyakarta: LPCR PP Muhammadiyah, Cetakan I, 2013

Moleong, Lexy, Metode Penelitian Kualitatif, Bandung: PT Remaja Rosdakarya, 2002
Mukti Ali, H.A., Memahami Beberapa Aspek Ajaran Islam, Bandung : Mizan, Cet. III, 1996

Mulyana, Deddy, Metodologi Penelitian Kualitatif Paradigma Baru Ilmu Komunikasi dan Ilmu Sosial Lainnya, Bandung: PT Remaja Rosdakarya, 2013

Odist, Aisyah, Mengelola Bank Sampah, Bersistem Konvensional Berbasis Rumah Tangga, Mataram : Bee Media Nusantara, $\mathrm{tt}$

Rahardjo, M. Dawam, "Pendekatan Ilmiah Terhadap Fenomena Keagamaan" dalam M. Taufik Abdullah dan M. Rusli Karim, Metodologi Penelitian Agama, Yogyakarta: Tiara Wacana, Cetakan II, 1990

Rakhmat, Jalaluddin, Psikologi Komunikasi, Bandung: PT Remaja Rosdakarya, 2013

Sairin, Sjafri, Perubahan Sosial Masyarakat Indonesia Perspektif Antropologi, Yogyakarta: Pustaka Pelajar, Cetakan I, 2002

Suciati, Psikologi Komunikasi Sebuah Tinjauan Teoritis dan Perspektif Islam, Yogyakarta: Buku Litera, 2015

Yafie, Ali, "Menjaga Alam itu Wajib" dalam Khazanah Republika co.id., Selasa, 30 Desember 2008 